\title{
INTERNAL AUDIT: THE APPLICATION OF RISK MANAGEMENT AND ELECTRONIC CHANNELS INTERNET BANKING THROUGH THE AUDIT MANAGEMENT SYSTEM IN THE QUALITY OF FINTECH GOVERNANCE IN BANKING INDUSTRY
}

\author{
Ika Barokah Suryaningsih \\ Faculty of Economics and Business, Universitas Jember \\ barokah.feb@unej.ac.id \\ Yuani Putrihandani \\ Faculty of Economics and Business, Universitas Brawijaya \\ Kristian Suhartadi Widi Nugraha \\ Faculty of Economics and Business, Universitas Jember
}

\begin{abstract}
This article aims to prove the role of internal auditors in providing added value in improving the quality of governance in the banking sector. The role of information technology in the banking industry sector is very dominant in service operations. This condition requires banks to apply their prudential principles by guaranteeing the implementation of risk management and electronic channel internet banking through audit management control systems. This study used an explanatory research approach with census data collection methods. The object of this study was the internal auditors of a branch office of one of the national private banks in Jember. The data of this study were the results of the response of 41 internal auditors of various branches and sub-branches in Jember Regency and supported by a literature review of the annual report of banks' internal audit performance with a path analysis data processing tool. The results of the study showed that the application of risk management and electronic channel internet banking had an effect on the audit management system and the quality of financial technology governance.
\end{abstract}

Keywords: audit, electronic channel, risk, financial technology

\begin{abstract}
Artikel ini bertujuan untuk membuktikan peran auditor internal dalam memberikan nilai tambah dalam meningkatkan kualitas tata kelola di sektor perbankan. Peran teknologi informasi di sektor industri perbankan sangat dominan dalam operasi layanan. Kondisi ini mengharuskan bank untuk menerapkan prinsip kehati-hatian mereka dengan menjamin penerapan manajemen risiko dan saluran elektronik internet banking melalui sistem kontrol manajemen audit. Penelitian ini menggunakan pendekatan penelitian eksplanatori dengan metode pengumpulan data sensus. Objek penelitian ini adalah auditor internal kantor cabang dari salah satu bank swasta nasional di Jember. Data penelitian ini adalah hasil dari respons 41 auditor internal dari berbagai cabang dan cabang pembantu di Kabupaten Jember dan didukung oleh tinjauan pustaka atas laporan tahunan kinerja audit internal bank dengan alat pengolah data analisis jalur. Hasil penelitian menunjukkan bahwa penerapan manajemen risiko dan saluran elektronik internet banking berpengaruh pada sistem manajemen audit dan kualitas tata kelola teknologi keuangan.
\end{abstract}

Keywords: audit, saluran eletronik, risiko,teknologi keuangan 
JEL: G3

\section{Research Background}

The quality of corporate governance will be the determinant of good and bad company performance including corporate banking services. Various attempts were made by corporate banking services to deliver the products required by the customer, one of which is the information technology-based services and/or products. Thus, the collaboration between the management, organization, and technology is necessary to create information systems solutions in improving the quality of service and reduce the cost (Loudon and Loudon 2015). It became the solution of business challenges in the digital age, where banks compete to provide and improve its services through the features of financial technology.

Financial technology-based service and product of banks do not always go well. Competition in business banking services and the level of success of the information systems can be a threat under conditions of uncertainty. This element becomes an important thing to notice for providers of banking services in conducting risk mitigation (van Deventer, Imai, and Mesler 2004; Sadgrove 2005). Banking that functions as an institute of mediation should provide a simple and secured service in every transaction. The risk faced by banking institutions becomes more complex as more and more transaction conducted based on the application of a financial technology-based system of information technology (Fahmi, 2013; Darmawi, 2014). Thus, the application of good risk management can be the driving factor of the success of the quality of corporate governance.

The quality of the governance of banking services is also inseparable from the application of an electronic channel for internet banking. Applications in the use of information technology through internet banking can improve efficiency, effectiveness, and productivity (Darmawi, 2012; Khoirunnisa and Sofik Handoyo 2014). Some examples of electronic channel based on information technology are: Automatic Teller Machine (ATM), Banking Application systems, Real-Time Gross Settlement System, Electronic Clearing System, and Internet Banking itself. In general, in the provision of internet banking services, the bank provides information about products and services via the portal on the internet, giving access to customers to transact and update his/her personal data.

The bank is a financial services company which is complex in its operational activities. The banking sector requires internal control as required by Bank Indonesia (BI) as the central bank in Indonesia, which sets the BI Regulation (PBI) No. 1/6/PBI/1999 on $20^{\text {th }}$ September 1999, article 9, letter (b) that stipulates "commercial banks shall form the Internal Audit Unit (SKAI) as the executor of the internal audit function". BI regulation became the foundation of banking in forming the internal audit division in each central office, branches, and subbranches.

The role and function of internal audit in the bank is critical because internal audit can help management as the guarantor and the division of security operations of the bank day-today. Assurance and security have become very important because $41 \%$ of funding source involves funds from the public (BCA Governance Annual report 2014). In undertaking its activities that must be independent, internal auditors are required to become a professional, so it should act as a guideline in the implementation of the internal audit function in banks. Assessment of the effectiveness of internal control is one of the scopes of work of internal audit. Corporate governance in banking is a major factor in maintaining the trust of shareholders and stakeholders towards a National Private Bank in Jember. This becomes important because of the increasing business challenges and the level of risk that must be faced by the banking industry. The application of the principles of good corporate governance is expected to help private banks in sustaining the banking business in a healthy and competitive condition. 
The development of information technology acts as a means towards the service improvement of the banking industry. Almost every bank competes to provide financialtechnology services through e-banking. The condition requires that every bank has internal control in which the internal audit division exists in order to provide added value and improve banking operations through the activities of the audit (assurance) and consultation that is independent and objective (BCA Governance Annual report 2016). On the governance report of private national banks 2017, the priorities of the Internal Audit division were: (a) the application of risk management in the use of information technology and enterprise security with respect to the complexity of the use of information technology in the company, (b) Electronic channel for Internet Banking that is in line with the increasing volume of transactions through e-channel, (c) Payment of card products and e-money in e-banking, (d) the Activity of issuing and acquiring business concerning the increase of card transactions, (e) the Process of commercial credit in maintaining the quality of the good commercial credit, (f) the Application of the Internal Control over Financial Reporting, (g) The implementation of good corporate governance, (h) The implementation of audit in Branch Office, Region, Division/Work Unit head office, and subsidiary company that is in accordance with the Annual Audit Plan which was established based on the results of risk assessment, (i) Improving the utilization of technology in the management of the audit activities through the development of Audit Management Systems, and (j) Developing and implementing proactive monitoring through continuous auditing and analytical review.

Quality of banking governance is essentially determined by the implementation of risk management and an electronic channel for internet banking. In addition, the audit management systems also determine the quality of the governance system of financial technology (fintech) offered. Therefore, the research gap in this research is to study the audit management systems as an intervening variable that mediates the effect of the application of risk management and electronic channel for internet banking on the quality of banking governance as shown in figure 1 .

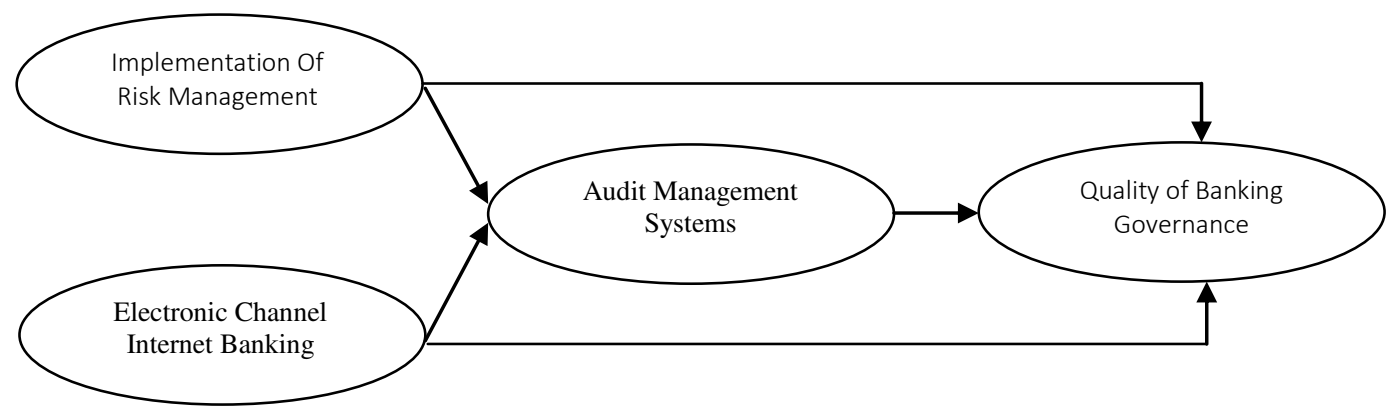

Figure 1. Conceptual Research Framework

Based on aforementioned theory, empirical studies, and the phenomenon, the purpose of this study is to test and prove the influence of the relationship of each variable, namely: (a) the effect of the implementation of risk management (X1) on audit management systems(Z); (b) the influence of Electronic Channel Internet Banking (X2) on audit management systems(Z); (c) the effect of the application of risk management (X1) on the Quality of Fintech Governance (Y); (d) the influence of Electronic Channel Internet Banking (X2) on the Quality of Fintech Governance (Y); and (e) the influence of the audit management systems (Z) and the Quality of Fintech Governance (Y) on the Internal Auditors of private national banks in Jember..

\section{Research Method}

This research was explanatory research with the object of 41 internal auditors of Private National Bank in Jember. Data types and sources used in this research were primary data. Data collection was done by undertaking direct observation, questionnaires supplemented with 
structured interviews to the objects, and a literature review of the report of the governance performance of the bank over the period of 2014-2017. Measurement techniques in this study used the Likert-scale to measure the opinion of internal auditors of Banks in Jember. The purpose of measurement was to transform the characteristics of the empirical data into a form that can be analyzed by the researcher. The Likert-scale provides a gradation from very positive to very negative and if the item is positive, then the largest number is placed on strongly agree. However, if the item is negative, then the largest number is placed on strongly disagree.

Instrument test in this research was done by test validity using the correlation of product moment Pearson's and test reliability using cronbach's alpha (Ghozali, 2013:48). An instrument said to be reliable if cronbach's alpha greater than 0.60 (Ghozali 2013:50).

The path analysis which is a technique of analysis used in conducting the analysis of inherent causal relationship between the variables were arranged based on temporary sequence using of the path coefficient as a magnitude of value in determining the magnitude of influence of independent variables on dependent variable (Duwi Priyatno 2010; Sarwono and Budiono 2010).

\section{Result and Discussion}

Based on the results of processing data using Path Analysis, it can be seen that all the variables that exist in the duties and functions of the internal auditor had an influence on the improvement of the quality of fintech banking governance. The results of the coefficient of direct effect among variables are presented in the following table.

Table 1. Path Coefficient Direct Influence

\begin{tabular}{|c|c|c|c|}
\hline Independent Variable & Dependent Variable & Coefficient & Sig. \\
\hline $\begin{array}{l}\text { Implementation of Risk } \\
\text { Management }\left(\mathrm{X}_{1}\right)\end{array}$ & Audit Management Systems (Z) & 0.772 & 0.012 \\
\hline $\begin{array}{l}\text { Electronic Channel Internet Banking } \\
\left(\mathrm{X}_{2}\right)\end{array}$ & Audit Management Systems (Z) & 0.586 & 0.003 \\
\hline $\begin{array}{l}\text { Implementation Of Risk } \\
\text { Management }\left(\mathrm{X}_{1}\right)\end{array}$ & $\begin{array}{l}\text { Quality of Banking Governance } \\
\text { (Y) }\end{array}$ & 0.561 & 0.008 \\
\hline $\begin{array}{l}\text { Electronic Channel Internet Banking } \\
\left(\mathrm{X}_{2}\right)\end{array}$ & $\begin{array}{l}\text { Quality of Banking Governance } \\
\text { (Y) }\end{array}$ & 0.486 & 0.011 \\
\hline Audit Management Systems (Z) & $\begin{array}{l}\text { Quality of Banking Governance } \\
\text { (Y) }\end{array}$ & 0,311 & 0,004 \\
\hline
\end{tabular}

Source: Data processed, 2018

Table 1 shows that the highest factor is the Implementation of Risk Management that reaches 0.772 and the influence of Electronic Channel Internet Banking that reaches 0.586 against the Audit Management Systems (Z). The direct influence of the Implementation of Risk Management and Electronic Channel Internet Banking on the Quality of Fintech Governance was 0.561 and 0.486 respectively. While the least influence was the Audit Management Systems against the Quality of Fintech Governance by 0.311 .

The indirect effect on the model image research framework model is as follows: first, The effect of implementation of Risk Management (X1) variable on Quality of Fintech Governance (Y) through the Audit Management Systems (Z). $\operatorname{IEyzx}_{1}=X_{1} \rightarrow \mathrm{Z} \rightarrow \mathrm{Y}=(0.772)(0.311)=$ 0.241 or $24.1 \%$. Second, The Influence of Electronic Channel Internet Banking (X2) on the Quality of Fintech Governance (Y) through the Audit Management Systems (Z). IEyzX ${ }_{2}=X_{2}$ $\rightarrow \mathrm{Z} \rightarrow \mathrm{Y}=(0.586)(0.311)=0.82$ or $18,2 \%$ 


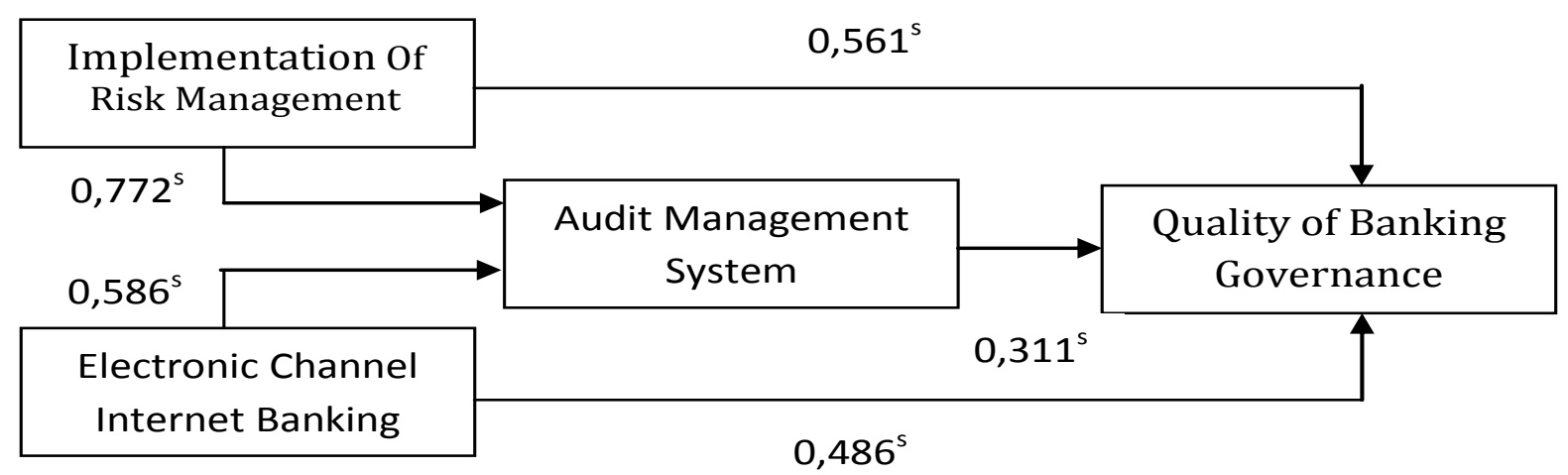

Figure 2. The Results of Research Model

The research results showed the implementation of risk management on the Internal Auditors of Private National Banks in Jember had a direct influence on the audit management systems with the result of 0.463 (of $46.3 \%$ ). The significance value on the implementation of risk management was 0.012 that is smaller than the significance level of $5 \%(0.05)$. This indicates that the implementation of good risk management can strengthen the audit management systems in the fintech governance of the banking industry. The implementation of risk management enables all employees of the bank in its operations to understand their duties so as to minimize the occurrence of errors in the service operations of the bank. In the variable of implementation of risk management, it is known that as many as 41 respondents, many of which gave a score of neutral towards the indicators of this variable, signifying that the presence of values in employees towards their job due to the ability of employees to analyze the risks of the job makes the audit management systems better. Therefore, understanding the application of risk management in the Internal Auditor of National Private Bank in Jember can lead to better audit management systems. This is in accordance with Cahyasumirat (2010) that concluded number of factors that affect the implementation of risk management, namely job challenge, employee satisfaction, career development opportunities, clear goals of the organization, as well as a balance between the needs of life and work.

The results showed that the Electronic Channel Internet Banking that is monitored by the Internal Auditors of Private National Banks in Jember had a direct influence on the audit of the management systems amounted to $0.498(49.8 \%)$. The significance level on the Electronic Channel Internet Banking was 0.003 meaning the path coefficient for the Electronic Channel Internet Banking had a significant effect on the quality of fintech governance. This indicates that the Electronic Channel Internet Banking that had a positive effect can lead to an increase in the quality of audit management systems. In variable of Electronic Channel Internet Banking, a significant positive effect of the audit management systems will be getting better along with the improvement of quality of service because of the increasing number of banking transactions through e-channel (Indria, David, and Joubert 2016; Laukkanen 2016).

Based on the results of the analysis, the implementation of risk management on the Internal Auditors of Private National Banks in Jember had a direct influence on the quality of fintech governance amounted to 0.561 (to $56.1 \%$ ). The significance value on the implementation of risk management was 0.008 that is smaller than the significance level of $5 \%$ (0.05), then the implementation of risk management provides a significant influence on the quality of fintech governance. It signifies that the implementation of risk management can cause an increase in the quality of fintech management. Thereby, it can be concluded that the implementation of risk management on the Internal Auditors of Private National Banks in Jember had an effect on the performance of the governance operations of the bank. According 
to Trisnaningsih (2007), commitment in applying risk management refers to consistency as a form of attachment a person against a certain thing, for example, commitment to a career. The existence of a commitment can be an encouragement for someone to work better or on the contrary cause a person to leave his job, as a result of demand for other commitments. Commitment will provide high motivation and a positive impact on job performance.

Based on the results of the study, the Electronic Channel Internet Banking in the implementation of the Internal Auditor of Private National Banks in Jember had a direct influence on the quality of governance fintech amounted to $0.486(48,6 \%)$. The significance level on the Electronic Channel for Internet Banking is 0.011 that is smaller than the significance value of 5\% (0.05), then the path coefficient for the Electronic Channel Internet Banking had a significant effect on the management of fintech banking. It can be interpreted that the product of the Electronic Channel for Internet Banking is e-banking (Asongu 2018) with a variety of services such as mobile BCA, Tunai BCA, atm BCA, or e-branch BCA (www.bca.co.id 2018) can be an indicator of the quality of the management of the fintech on the banking sector.

The influence of management audit system on the Internal Auditors of Private National Banks in Jember had a direct influence on the Quality of Fintech Governance amounted to $0.311(31.1 \%)$. The significance of the values on the audit of the management system was 0.004 that is smaller than the significance value of $5 \%(0,05)$, then the path coefficient for the audit management systems had a significant influence on the Quality of Fintech Governance. This indicates that the quality of audit management led to an increase in the quality of fintech management on the operations of the bank. It can be interpreted that the level of audit management systems in the management of banking leads to quicker and more accurate service and performance. Therefore, it can be concluded that the audit management systems on the Internal Auditors of private bank had an influence on the Quality of Fintech Governance (Inna and Kudinska 2016).

The results of data processing of Internal Auditors of the National Private Banks in Jember showed that the implementation of risk management (X1) had a direct effect on the audit management systems (Z) by $46.3 \%$, and the implementation of risk management (X1) had a direct effect on the quality of fintech governance (Y) amounting to $37.3 \%$. On the other hand, no direct influence of the implementation of risk management (X1) on the quality of governance fintech banking (Y) through the audit management systems $(\mathrm{Z})$ which is equal to 0.229 or $22.9 \%$. Based on these calculations, the influence of the direct application of risk management more of $46.3 \%$ and $37.3 \%$ compared to the direct effect, which only amounted to $22.9 \%$. It signifies that audit management systems $(\mathrm{Z})$ are not a mediating variable of the implementation of risk management (X1) on the quality of fintech governance (Y). Thus, the implementation of risk management $(\mathrm{X} 1)$ and audit management systems $(\mathrm{Z})$ is better to be independent variables on the quality of fintech governance $(\mathrm{Y})$.

The results of research conducted on the Internal Auditors of Private National Banks in Jember showed that the Electronic Channel for Internet Banking (X2) had a direct effect on the audit management systems (Z) amounted to $49.8 \%$ and Electronic Channels Internet Banking (X2) had a direct effect on the Quality of Fintech Governance (Y) by 31.6\%. While Electronic Channel for Internet Banking (X2) had no direct effect on the Quality of Fintech Governance (Y) through the audit management systems (Z) of 18.2\%. Based on these results, the Electronic Channel for Internet Banking (X2) had a higher value of influence with $49.8 \%$ and $31.6 \%$ compared to the direct effect of only $18.2 \%$. Thus, the Audit Management Systems ( $\mathrm{Z}$ ) is a pseudo-mediating variable so that the Electronic Channel Internet Banking (X2) and Audit Management Systems (Z) would be better to be independent variables on the Quality of Fintech Governance (Y). 


\section{Conclusion}

The audit management systems in the banking sector are the main foundation of the performance of the quality of fintech governance. The audit management systems are closely related to the implementation of risk management, Electronic Channels, Internet Banking, and the quality of fintech governance. Based on the discussion in this article, it can be concluded that: (a) the implementation of risk management (X1) had a significant effect on audit management systems (Z); (b) Electronic Channel Internet Banking (X2) had a significant effect on audit management systems (Z); (c) the implementation of risk management (X1) had a significant effect on Quality of Fintech Governance (Y); (d) Electronic Channel Internet Banking (X2) had a significant effect on Quality of Fintech Governance (Y); and (e) the audit management systems (Z) had a significant effect on the Quality of Fintech Governance (Y) on Internal Auditors of private national banks in Jember.

\section{Acknowledgement}

Thanks to Mahmud Fatoni PT. BCA., Tbk Jember Deputy Manager as a key person in the research data collection.

\section{References}

Asongu SA. 2018. Conditional Determinants of Mobile Phones Penetration and Mobile Banking in Sub-Saharan Africa. Journal of the Knowledge Economy.

BCA [internet]. 2018. [Cited in 2018 September 3]. Available from www.bca.co.id Cahyasumirat G. 2010. Pengaruh Profesionalisme Dan Penerapan manajemen risikoTerhadap Kinerja Internal Auditor, Dengan Kepuasan Kerja Sebagai Variabel Intervening (Studi Empiris Pada Internal Auditor PT. Bank Abc). [Skripsi]. Semarang: Universitas Diponegoro.

Darmawi H. 2012. Manajemen Perbankan. Jakarta: Bumi Aksara.

Darmawi H. 2014. Manajemen Risiko. Jakarta: Bumi Aksara.

Duwi P. 2010. Teknik Mudah dan Cepat Melakukan Analisis Data Penelitian dengan SPSS dan Tanya Jawab Ujian Pendadaran. Yogyakarta: Gaya Media.

Fahmi I. 2013. Manajemen Risiko:Teori, Kasus, dan Solusi. Bandung: Alfabeta publisher.

Ghozali I. 2013. Analisis Multivariat dengan Program SPSS (Multivariate Analysis with SPSS Program). Semarang: Universitas Diponegoro.

Indria SK, David PE, Saerang, Maramis J. 2016. ANALISIS FAKTOR-FAKTOR KUNCI PENGGUNAAN INTERNET BANKING (Studi Kasus Pada PT. BNI (Persero) Tbk. Kantor Cabang Manado). Jurnal EMBA. 4(5): 522-530.

Inna R, Kudinska M. 2016. Banking and Fintech: A Challenge or Opportunity? Contemporary Issues in Finance: Current Challenges from Across Europe. British: Publisher Emerald Group Publishing Limited.

Khoirunnisa I, Handoyo S [internet]. 2014. Analisis Efisiensi Penggunaan Electronic Channel Pada Industri Perbankan Di Indonesia Dengan Menggunakan Data Envelopment Analysis (DEA). [Cited in 2018 December 23]. Available from journal.feb.unpad.ac.id/index.php/jak/article/ download/101/62.

Laporan Tahunan Tata Kelola BCA [internet]. 2018. [Cited in 2018 September 2]. Available fromhttps://www.bca.co.id/id/TentangBCA/ /media/33918614A65C4A68B4B3522992 EF4A4F.ashx.

Laudon KC, Laudon JP. 2015. Sistem Informasi Manajemen: Mengelola perusahaan Digital $13^{\text {th }}$ ed. Jakarta: Salemba Empat.

Laukkanen T. 2016. Consumer adoption versus rejection decisions in seemingly similar service innovations: The case of the Internet and mobile banking. Journal of Business Research. 
Nur A, Gevi. 2014. Pengaruh Komitmen Organisasi, Locus of Control, dan Kompleksitas Tugas Terhadap Kinerja Auditor Internal (Survei Penelitian Pada PerusahaanPerusahaan Bumn Di Kota Bandung). [Skripsi ]. Fakultas Ekonomi Universitas Widyatama.

Sadgrove K. 2005. The Complete Guide to Business Risk Management. Burlington: Gower Publishing Limited.

Saputra KAK. 2012. Pengaruh Locus Of Control Terhadap Kinerja Dan Kepuasan Kerja Internal Auditor Dengan Kultur Lokal Tri Hita Karana Sebagai Variabel Moderasi. Jurnal Akuntansi Multiparadigma. 1-160.

Sarwono J, Budiono H. 2012. Statistik Terapan, Aplikasi untuk Riset Skripsi, Tesis, dan Disertasi (Menggunakan SPSS, AMOS, dan Excel). Jakarta: PT Elex Media Computindo.

Trisnaningsih S. 2007. Independensi Auditor Dan Penerapan manajemen risikoSebagai Mediasi Pengaruh Pemahaman Good Governance, Gaya Kepemimpinan Dan Budaya Organisasi Terhadap Kinerja Auditor. Jurnal Universitas Pembangunan Nasional (UPN) "Veteran" Jawa Timur. 22.

Van Deventer DR, Kenji I, Mark M. 2004. Advanced Financial Risk Management: Tools \& Techniques for Integrated Credit Risk and Interest Rate Risk Management. New York: John Wiley. 